\title{
Two Faces of Flow: Preliminary Results From a Game Addiction Study
}

\section{Katarzyna Skok}

University of Bialystok | kskok488@gmail.com | 0RCID: 0000-0002-1309-9674

\begin{abstract}
This study aims to explore the ambiguous nature of flow and the way it relates to inclination towards addiction. The results of an exploratory factor analysis indicate that the flow experienced by players has at least two components which are called in this study hedonistic flow (direct pleasure seeking) and eudaimonistic flow (escapism). The results of the regression analysis show that $54.4 \%$ of the variance of Internet addiction is accounted for by life competence, eudaimonistic flow in a game, excitement as an emotion experienced while playing a game and annoyance as an emotion experienced when it is not possible to play.
\end{abstract}

Keywords: game addiction, flow, eudaimonism, excitement, escapism 



\section{Introduction}

Internet (game) addiction is often labeled as problematic Internet (game) use and could be characterized by an individual's inability to control his or her Internet (game) use, which in turn leads to feelings of distress and to a functional impairment of daily activities (Shapira at al., 2003) The clinical interpretation of Internet (game) addiction has brought many controversies. It is still not included in the current DSM or ICD classifications ${ }^{1}$. On the one hand, Internet addiction shows a strong diagnostic similarity to DSM-IV's substance dependence (Young, 1996) and demonstrates a pattern similar to compulsive gambling (Young, 1998; Greenfield, 1999). On the other hand, some researchers argue that Internet compulsion may be masking other problems (Walther, 1999; Griffiths, 2000; Davis, 2001).

The second theory on which the research described in this paper is based is that of flow. The concept of flow was introduced by Csikszentmihalyi (1990) to describe the optimal experience - the state in which someone is fully focused on a pleasant activity and when there is a balance between skills and challenges. Flow experiences can be characterized by intense and focused concentration, merging of action and awareness, loss of reflective self-consciousness, sense of control over one's actions, distortion of the sense of time, clear goals, immediate feedback, and intrinsic reward. Such characteristics seem to fit the course of gameplay well and some studies indicate a positive relation between flow and game addiction (Choi \& Kim, 2004; Chou \& Ting, 2003). There is, however, also an opposite voice which shows a negative correlation between flow and inclinations toward addiction (Wan \& Chiou, 2006). In this study, the level of the flow experience was significantly lower for addicts than for non-addicts.

Is the flow experience responsible for inclinations toward addiction? The first position assumes only the positive perspective on flow - which seems justified, as the flow state is related to a positive affect. The second

1 DSM (Diagnostic and Statistical Manual of Mental Disorders) and ICD (International Statistical Classification of Diseases and Related Health Problems) are publications used for diagnostic purposes. 
one highlights the negative perspective and is based on the motivational premises of Maslow's hierarchic theory of needs. It differentiates lower dissatisfactory needs (physiological needs, safety, love/belonging, selfesteem) from higher satisfactory needs (self-actualisation, transcendence). The authors representing the second position (Wan \& Chiou, 2006) assume that satisfying lower needs does not lead to higher satisfaction. They indicate that both types of needs describe entirely different dimensions and should not be treated as two poles of a single dimension. According to these authors, addiction features are more typical to lower dissatisfactory needs than to higher satisfactory needs. Compulsive playing seems to stem from the relief of dissatisfaction rather than the pursuit of satisfaction. In contrast, games tend to provide the non-addicts with a sense of satisfaction rather than a sense of dissatisfaction.

One of the purposes of the current study was the exploration of this difference. This exploration might explain the contradicting results described by the 'positive' and 'negative' perspectives mentioned above. If the difference is a fact, addicts would be motivated by a kind of compensation ('I'd feel bad if I didn't play') and non-addicts by fun ('When I play, I feel good').

Both types of players would experience the flow state as introduced by Csikszentmihalyi, but they would be focused on its different characteristics: either clearly 'positive' ones (fun) or those slightly 'negative' (loss of reflective self-consciousness, forgetfulness). The distinction between 'positive' and 'negative' characteristics might evoke undesirable associations so both flow perspectives - based on their key features - are called in this study hedonistic and eudaimonistic.

Both hedonism and eudaimonism have their sources in ancient Greek

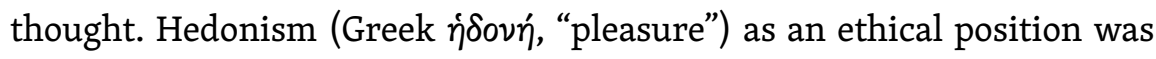
developed by Aristippus of Cyrene and indicated that pleasure is the only good. 'Positive' flow is hedonistic in nature because it implies experiencing pleasure. An online game which does not give fun stops being attractive.

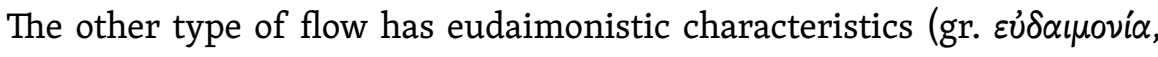
"happiness"). Eudaimonism is a broader perspective but it can be described in relation to hedonism - the former views happiness in the same way as the latter does pleasure (Tatarkiewicz, 1976). Eudaimonism - in contrast to hedonism - accepts a number of different paths leading to happiness. 
In current psychology both approaches have given rise to different views on the nature of well-being. If the concept of well-being refers to optimal psychological functioning and experience (Ryan \& Deci, 2001), then - depending on the point of view - it can be interpreted either in terms of pleasure and happiness (Kahneman, Diener \& Schwarz, 1999) or actualisation of human potentials (Waterman, 1993). It is worth noting than the idea of flow examined in the current article is congruent with both of these positions and encompasses components mentioned by Csikszentmihalyi (1990). If eudaimonistic flow can be characterized by the need for happiness and fulfillment, then escape (compensation) is a core of this experience (this has not been noticed before). Fulfilling or realising one's daimon or true nature (Waterman, 1993) implies understanding of the imperfectness of human life and the pursuit of ultimate meaning which cannot be reduced to a mere pleasure. Compensation is inevitable here because it guarantees personal growth and feelings of competency in spite of objective obstacles an individual may meet on the way to happiness. It can be hypothesised here that an online game which does not give fun anymore is rejected by individuals oriented hedonistically but not eudaimonistically (as compensating life deficits with a game does not necessarily need to be pleasant). As noticed by McMahan and Estes (2011), running a marathon provides more opportunities for personal growth than dining at a fine restaurant. In terms of flow: dining at a fine restaurant provides short-time pleasure (fun) and running a marathon (and preparing to it) gives meaning that can occupy the mind for a longer time.

An Internet (game) addict who is refused their favorite way of escaping may perceive their own offline deficits much more deeply, which in turn may lead to withdrawal symptoms characteristic of addiction. An individual motivated eudaimonistically is determined to achieve some broader goal than mere pleasure.

Eudaimonistic and hedonistic flow seem to be two faces of the traditional flow. They describe different ways people are motivated to certain behaviors. Intense and focused concentration, merging of action and awareness, loss of reflective self-consciousness, and time distortion might be more essential to eudaimonistic flow (escape, forgetting), and clear goals, immediate feedback, and intrinsic reward might be more 
relevant to the hedonistic one (pleasure). The twofold characteristics of the optimal experience can be better understood in the light of the promotion-prevention theory (Higgins, 1997). In the context of online games, promotion behaviors are those motivated by fun, curiosity, or achievements (embracing pleasure). On the other hand, the aim of prevention behaviors is distraction and escape (avoiding pain).

\section{The Current Study}

The hypotheses in the current study reflected the differences in flow experienced by players who were more and less inclined toward addiction. It was assumed that the differences would be observed both online (in-game) and offline (in real-life activities).

- H1. More addicted players will be:

- H1.1. less satisfied with their lives than less addicted players.

- H2. Differences between more addicted players and less addicted players in the flow experienced offline and in-game will be the following:

- H2.1. Less addicted players will experience a higher level of flow offline than in-game.

- H2.2. More addicted players will experience a higher level of flow in-game than offline.

- H2.3. More addicted players will experience in-game a higher level of flow than less addicted players.

- H2.4. More addicted players will experience offline a lower level of flow than less addicted players.

- H3. Differences between more addicted players and less addicted players in experiencing eudaimonistic and hedonistic flow will be the following:

- H3.1. The level of eudaimonistic flow experienced in-game will be higher for more addicted players than less addicted ones.

- H3.2. The level of hedonistic flow experienced in-game will be higher for less addicted players than more addicted ones.

- H3.3. The level of hedonistic flow experienced offline will be higher for less addicted players than more addicted ones. 
- H3.4. More addicted players will experience in-game a higher level of eudaimonistic flow than that of hedonistic flow.

- H3.5. Less addicted players will experience in-game a higher level of hedonistic flow than that of eudaimonistic flow.

\subsection{Method}

The research was conducted online in Polish after placing recruitment information about the survey on six Polish language online game forums. There was no interaction between participants and researchers. After clicking a link in the recruitment note, individuals were redirected to the webpage with the survey.

\subsubsection{Materials}

The study questionnaire consisted of 70 single items and two complex items related to emotions. For each item, participants were required to specify their level of agreement or disagreement on a 5-point Likert scale. The questionnaire was followed by three questions regarding the average weekly time spent in game, the duration of playing (when it was started), and the names of the games played. The language of the questionnaire was Polish.

Flow level was measured by two exploratory scales prepared for the purposes of the current study, each consisting of 18 items. One scale measured flow experienced while playing an online game, the other one measured flow experienced in general (in life). Consecutive items in both scales corresponded to each other in such a way that the flow-inlife scale was a generalisation of statements from the flow in game scale. The instruction for the flow in game scale asked players to imagine that they were playing their favorite game. Consequently, the instruction for the flow in life scale asked them to think about their life in general. Items from both scales were presented on a single HTML page in random order - different for each participant (which might have affected the reliability score).

Addiction was measured with the Internet Addiction Test (Widyanto \& McMurran, 2004) and satisfaction with life was measured with the Satisfaction with Life Scale (Diener at al., 1984). Additionally, two exploratory scales were used, concerning emotions experienced while playing 
and emotions experienced when it is not possible to play, based on a twofactor model of emotions (Russell at al., 1989). The pleasant and higharousal emotions (excitement) were: excited, interested, glad, happy; the unpleasant and high-arousal emotions (stress) were: stressed, angry, irritated, annoyed, frustrated, anxious; the pleasant and low-arousal emotions (relaxation) were: relaxed, calm; and finally the unpleasant and low-arousal emotions (depression) were: bored, disappointed, tired, sad.

\subsubsection{Participants}

The participants were Polish language players recruited from Polish online game forums. The recruitment note informed that the study would explore their motivation to play online games. The analysis included 159 surveys of which 111 were fully filled out. Players who filled out the whole survey were of the following age groups: 19-24 (47.7\%; 53 participants), under 19 (32.4\%; 36 participants), and over 24 (19.8\%; 22 participants). The played games were the following: World of Warcraft (53\%; 84 participants), Battlefield (9\%; 14 participants), Lineage II (8\%; 13 participants), Runes of Magic (8\%; 13 participants), and Guild Wars (2\%; 3 participants).

\subsubsection{Results}

Addiction. The mean level of Internet addiction (111 results from fully filled out surveys) was 41.22 .80 participants $(72.1 \%)$ were diagnosed as average Internet users, 30 participants $(27 \%)$ were users experiencing occasional or frequent problems because of the Internet, and one person (0.9\%) was an addicted one. Because the aim of the current study was not a clinical one, it was decided to assume a median for differentiating participants in relation to their level of addiction. According to these statistics, 55 participants were assigned to the group of less addicted players $(49.5 \%)$ and $56(50.5 \%)$ to the group of more addicted players. Both groups of players got respectively 21 to 37 and 38 to 88 points on the Internet Addiction Test.

Addiction and age. There was no significant correlation between Internet addiction and age: $r(109)=0.02 ; p=0.87$. The mean levels of addiction of participants from different age groups were the following: individuals under 19: $M(36)=41.94, S D=16.18$; individuals between 19 and 24: $M(53)=39.89$, $\mathrm{SD}=11.99$; and individuals over $24: \mathrm{M}(22)=43.23, \mathrm{SD}=16.73$. 
Verification of hypotheses. From 18 flow items presented in the survey, eventually 12 were chosen for further analysis. Exploratory factor analysis (Varimax rotation with Kaiser normalisation) of flow in game state showed three factors: eudaimonistic flow (six items; $\alpha=0.71 ; 20.57 \%$ of variance), hedonistic flow (three items; $\alpha=0.65 ; 15.43 \%$ of variance) and purposefulness (three items; $a=0.41 ; 12.54 \%$ of variance). These factors explain $48.54 \%$ of the variance of results. Eudaimonistic flow includes absorption, forgetting problems, meaning, calming down, filling emptiness in life, and escape from nonsense. Hedonistic flow includes fun, curiosity, and autonomy. And purposefulness includes purposefulness, achievability of goal, and challenge. Purposefulness had a low reliability, which indicates that it should be reworked in future (either developed as a single factor or merged with the two existing ones).

Factor analysis of flow in life did not show a similar pattern as flow in game. For example, absorption seemed to be rather a part of purposefulness or a factor representing hedonistic flow not eudaimonistic one. Additionally, eudaimonistic flow seemed to lack some of its components: calming down or meaning are not a part of it but clearly form a hedonistic state. This fact may indicate that, from a psychometric point of view, flow in life is not an equivalent of the flow experienced during some activities. For further analysis, it was nonetheless decided to operationalize flow in life by items corresponding to flow in game. Table 1 shows the rotated component matrix of flow in game.

Of the 10 tested hypotheses, 7 were verified positively. More addicted players compared to less addicted ones were less satisfied with their lives (H1.1) $(M=13.84$ and $M=16.6 ; t(109)=3.64 ; p<0.01)$. As far as the second hypothesis is concerned, two of its parts were verified positively and two negatively. Contrary to the assumptions, less addicted players did not experience a higher level of flow in life than while playing games (H2.1). The level of flow experienced by this group in games and in life was similar (respectively: $M=3.51$ and $M=3.63 ; t(53)=-1.42 ; p=0.16$ ). In the group of more addicted players the difference was consistent with the hypothesis (H2.2): more addicted players experienced a higher level of flow in game than in life $(M=3.77$ and $M=3.49 ; t(55)=2,82 ; p<0.01)$. Additionally, more addicted players experienced a higher level of flow in game than less addicted ones $(\mathrm{H} 2.3)(M=3.77$ and $M=3.5 ; t(109)=-2.82 ; p=0.01)$. 
Hypothesis 2.4 was not supported: both groups of players experienced similar levels of flow in life (more and less addicted players, respectively: $M=3.49$ and $M=3.63 ; t(108)=1.27 ; p=0.21)$.

Table 1. Results of exploratory factor analysis of flow in game - factor loadings (rotation method: Varimax with Kaiser normalisation)

\begin{tabular}{|cc|c|c|}
\hline \multirow{2}{*}{ Items } & \multicolumn{3}{c|}{ Flow in game } \\
& Eudaimonistic & Hedonistic & Purposefulness \\
\hline absorption & 0.493 & 0.097 & 0.311 \\
\hline forgetting problems & 0.771 & 0.013 & -0.003 \\
\hline meaning & 0.614 & 0.163 & 0.211 \\
\hline calming down & 0.589 & 0.020 & -0.029 \\
\hline filling emptiness in life & 0.687 & 0.193 & -0.180 \\
\hline escape from nonsense & 0.614 & -0.025 & 0.092 \\
\hline fun & -0.006 & 0.792 & 0.225 \\
\hline curiosity & 0.108 & 0.783 & 0.156 \\
\hline autonomy & 0.121 & 0.677 & -0.086 \\
\hline purposefulness & -0.088 & 0.136 & 0.702 \\
\hline achievability of goal & 0.115 & 0.230 & 0.411 \\
\hline challenge & 0.101 & -0.093 & 0.760 \\
\hline
\end{tabular}

The third hypothesis, depicting the differences between more and less addicted players in experiencing hedonistic and eudaimonistic flow, was supported in its three components. First (H3.1), the level of eudaimonistic flow experienced in game was higher for more addicted players than less addicted ones $(M=3.21$ and $M=2.55 ; t(109)=-4.28 ; p<0.01)$. Second (H3.3), the level of hedonistic flow experienced in life was higher for less addicted players than more addicted ones $(M=3.88$ and $M=3.51 ; t(108)=2.37 ; p=0.02)$. Third (H3.5), for less addicted players the level of hedonistic flow experienced in game was higher than the level of eudaimonistic one $(M=4.25$ and $M=2.55 ; t(54)=16.58 ; p<0.01)$. Contrary to the assumptions, hypotheses $\mathrm{H} 3.2$ and $\mathrm{H} 3.4$ were not supported. The level of hedonistic flow experienced in game was not higher for less addicted players than for more addicted ones (H3.2) $(M=4.36$ and $M=4.25 ; t(109)=-0.99 ; p=0.33)$. Also (H3.4), more addicted players did not experience in game a higher level of eudaimonistic flow than that 
of hedonistic flow. On the contrary, the group of more addicted players experienced a higher level of hedonistic flow than that of eudaimonistic flow $(M=4.36$ and $M=3.21 ; t(55)=8.84 ; p<0.01)$.

In response to the negatively verified hypothesis 3.4 , a more subtle measure can be submitted, regarding a general difference in experiencing hedonistic and eudaimonistic flow in game. For all participants hedonistic flow in game was significantly stronger than eudaimonistic one $(M=4.30$ and $M=2.91 ; t(158)=-19.32 ; p<0.01)$. If we test the hypothesis 3.4 in relation to this difference, its meaning is verified positively. The difference between hedonistic and eudaimonistic flow in game was significantly lower for more addicted players than for less addicted ones $(M=1.15$ and $M=1.69 ; t(109)=3.29 ; p<0.01)$. This may reflect a relatively higher significance of eudaimonistic flow (compared to hedonistic one) for more addicted players. What is interesting, a contrary difference can be observed in the level of flow experienced in life $[M=0.07$ (more addicted players) and $M=0.56$ (less addicted players); $t(108)=3.06$; $\mathrm{p}<0.01$ ). In both cases (flow in games or flow in life) the difference can be accounted for by different factors. In the first case, the level of eudaimonistic flow in game was higher for more addicted players than for less addicted ones (H3.1) but there was no difference in experiencing hedonistic flow in game (H3.2). In the second case, the level of hedonistic flow in life was higher for less addicted players than for more addicted ones (H3.3) but there was no difference in experiencing eudaimonistic flow in life $[M=3.44(A P)$ and $M=3.32$ (NAP); $t(108)=-0.91 ; p=0.37$ ).

Emotions. Emotions experienced while playing a favorite game or when it is not possible to play were analyzed according to the two-factor model of emotions (Russell et al. 1989). The participants experienced more intensely pleasant emotions [excitement $(M=3.75)$ and relaxation $(M=3.41)$ ] when they were playing than unpleasant emotions [depression $(M=1.80)$ and stress $(M=1.58)]$ when they were unable to play.

Three categories of emotions correlated positively with addiction: stress, depression, and excitement. Eudaimonistic flow correlated positively with all categories. There was no correlation between any emotion category and hedonistic flow in life or life satisfaction. The pleasant emotions correlated with addiction, hedonistic and eudaimonistic flow 
in games, and eudaimonistic flow in life. The unpleasant emotions correlated with addiction and eudaimonistic flow in games and life. Detailed correlation statistics are presented in Table 2.

Table 2. Correlations between emotional states and other variables tested in the study

\begin{tabular}{|c|c|c|c|c|c|c|c|}
\hline & & & Correlations & with other vari & iables tested in & he study & \\
\hline & Emotions & aldi. & Flow in & jame & Flow in & life & Satisfaction \\
\hline & & & Eudaimonistic & Hedonistic & Eudaimonistic & Hedonistic & \\
\hline & excitement & $0.34 * * *$ & $0.35^{* * *}$ & $0.34 * * *$ & $0.29 * *$ & 0.04 & 0.13 \\
\hline & stress & $0.65^{* * *}$ & $0.54 * * *$ & 0.03 & $0.22 *$ & -0.08 & -0.17 \\
\hline & relaxation & -0.02 & $0.25^{* *}$ & $0.22^{* *}$ & $0.24^{* *}$ & 0.11 & 0.18 \\
\hline & depression & $0.57 * * *$ & $0.56^{* * *}$ & 0.14 & $0.23 *$ & -0.02 & 0.12 \\
\hline & excited & $0.42 * * *$ & $0.23 * *$ & 0.20 * & 0.15 & -0.09 & -0.01 \\
\hline & interested & $0.22 *$ & $0.23^{* *}$ & $0.37^{* * *}$ & $0.24^{* *}$ & 0.07 & 0.17 \\
\hline & glad & 0.20 * & $0.23 * *$ & $0.23 * *$ & $0.24 * *$ & 0.10 & $0.22 *$ \\
\hline & happy & 0.18 & $0.37 * * *$ & 0.27 ** & $0.26^{* *}$ & 0.08 & 0.12 \\
\hline & stressed & $0.42 * * *$ & $0.42 * * *$ & -0.02 & $0.22^{*}$ & 0.03 & 0.01 \\
\hline & angry & $0.55^{* * *}$ & $0.39 * * *$ & 0.04 & 0.20 * & -0.04 & $-0.22^{*}$ \\
\hline & irritated & $0.46^{* * *}$ & $0.41 * * *$ & 0.06 & 0.08 & -0.15 & -0.14 \\
\hline & annoyed & $0.59 * * *$ & $0.43 * * *$ & 0.04 & 0.20 * & -0.06 & -0.10 \\
\hline$B$ & frustrated & $0.50 * * *$ & $0.47^{* * *}$ & 0.07 & $0.19 *$ & -0.05 & -0.08 \\
\hline & anxious & $0.57 * * *$ & $0.45^{* * *}$ & -0.05 & $0.19 *$ & -0.10 & $-0.28 * *$ \\
\hline & relaxed & 0.00 & 0.17 * & $0.29 * * *$ & $0.18 *$ & 0.03 & 0.16 \\
\hline & calm & -0.03 & $0.24^{* *}$ & 0.10 & $0.22 *$ & 0.15 & 0.15 \\
\hline & bored & $0.48 * * *$ & $0.50 * * *$ & $0.16^{*}$ & 0.15 & -0.02 & -0.15 \\
\hline & $\begin{array}{l}\text { disappoin- } \\
\text { ted }\end{array}$ & $0.42 * * *$ & $0.36 * * *$ & 0.10 & 0.12 & -0.01 & -0.08 \\
\hline & tired & $0.34 * * *$ & $0.35^{* * *}$ & 0.11 & $0.22 *$ & 0.03 & -0.01 \\
\hline & sad & $0.48 * * *$ & $0.43 * * *$ & 0.02 & $0.24 * *$ & -0.06 & -0.09 \\
\hline & ${ }^{*} p<0.05$ & & & ${ }^{* *} p<0$. & mot & al states & \\
\hline & ${ }^{*} p<0.01$ & & & $B-s i$ & ngle emotions & & \\
\hline
\end{tabular}




\section{Eudaimonistic flow and an excitement-based model of Internet addiction.}

It was assumed that a distal cause of Internet or game addiction is a low life competence (operationalized by the flow in life item 'I know I do well in life'), and annoyance is an emotion experienced when it is not possible to compensate that low competence (for example, by playing a game). The compensation itself paradoxically might be based on experiencing higharousal pleasant excitement and soothing eudaimonistic flow at the same time. It is important to add that excitement is not identical with hedonistic flow (although it can be a main emotion experienced while being in this state). Also, excited players are not necessarily in the hedonistic state, their excitement may be a way to escape.

Linear regression analysis showed that $54.4 \%$ of the variance of Internet addiction was accounted for by the four above factors. Detailed regression analysis results are presented in Tables 3 and 4 .

Table 3. Results of linear regression analysis for internet addiction model summary

\begin{tabular}{cccc}
$R$ & R Square & Adjusted R Square & $\begin{array}{c}\text { Std. Error of the } \\
\text { Estimate }\end{array}$ \\
\hline 0.749 & 0.561 & 0.544 & 9.743 \\
\hline
\end{tabular}

Table 4. Results of linear regression analysis for internet addiction coefficients

\begin{tabular}{|c|c|c|c|c|c|}
\hline & \multicolumn{2}{|c|}{$\begin{array}{l}\text { Unstandardized } \\
\text { Coefficients }\end{array}$} & \multirow{2}{*}{$\begin{array}{c}\text { Standardized } \\
\text { Coefficients } \\
\text { Beta }\end{array}$} & \multirow[t]{2}{*}{$t$} & \multirow[t]{2}{*}{ Sig. } \\
\hline & B & Std. Error & & & \\
\hline (constant) & 21.787 & 4.754 & & 4.583 & 0.000 \\
\hline excitement & 3.669 & 0.920 & 0.272 & 3.986 & 0.000 \\
\hline $\begin{array}{l}\text { eudaimonistic } \\
\text { flow in game }\end{array}$ & 3.565 & 1.235 & 0.217 & 2.887 & 0.005 \\
\hline annoyance & 5.813 & 1.052 & 0.410 & 5.526 & 0.000 \\
\hline life competence & -3.985 & 0.859 & -0.301 & -4.638 & 0.000 \\
\hline
\end{tabular}




\section{Discussion}

The results of the study show that there is a positive correlation between Internet (or game) addiction and flow in game. More addicted players tend to be less satisfied with life. Additionally, games seem to be a special form of activity for them: they experience more flow in game than generally in life and the level of their flow is higher than that experienced by less addicted players. This study shows that flow is not a homogenous state as introduced by Csikszentmihalyi; therefore, its relation to addiction is much more complex than depicted in the literature. Flow experienced by players has at least two components which relate to (1) direct pleasure seeking, 'here and now' enjoyment of performing an action (hedonistic flow), and to (2) the need to compensate life deficits (eudaimonistic flow, a kind of escapism). Less addicted players experience more hedonistic flow in life than more addicted ones, and in games the opposite is true: the level of eudaimonistic flow in games is higher for more addicted players than for less addicted ones.

In terms of the promotion-prevention theory (Higgins, 1997), hedonistic flow corresponds to promotion and eudaimonistic one is related to prevention. There is, however, one interesting paradoxical incongruence here. More addicted players compared to less addicted ones experience a higher level of eudaimonistic flow in game (prevention), and at the same time they are more excited while playing (promotion). This paradox can be explained by assuming that, in addiction, promotion and prevention correspond to different motivational levels. Prevention, or eudaimonistic flow, is a meta-metamotivational strategy while promotion, or excitement, is a metamotivational tactic to perform certain actions in games. The above relations are presented in Table 5. A similar pattern was observed in experimental conditions - risky tactics can serve a vigilant strategy (Scholer at al., 2008).

In the current study, preventional regulation, vigilance, and eudaimonistic flow are a reaction to low life competence, to deficits and problems that cannot be coped with in a direct way. When typical off-game prevention strategy is not successful and individuals are prone to failure, they modify their tactics under the strategy and seek excitement (instead of relaxation) in a game. Instead of being focused on their life deficits they become 
excited by games. The model of game (Internet) addiction presented in the current study includes four predictors: low (1) life competence that leads to (2) annoyance when it is not possible to compensate it, (3) eudaimonistic flow in a game as a strategy to prevent experiencing future failures, and (4) excitement as a tactic to reach strategic goals in the best way. This corresponds to the results of physiological studies on Internet and game addiction. Addicts tend to have a higher level of physiological arousal than non-addicts (Griffiths \& Dancaster, 1995). High 'energetic' arousal is typical for a type A personality and those who score high on Behavioral Activation System (BAS) scales (Carver \& White, 1994). Although there is no direct empirical evidence for a relation between BAS and Internet (game) addiction, some studies show that BAS may influence alcohol or drug addiction (Franken, 2002; Franken \& Muris, 2006). Two components of BAS might be especially responsible for this: fun seeking and drive.

Table 5. Levels of motivation and corresponding goals, promotionprevention states and types of flow

\begin{tabular}{cccc}
\hline Motivation level & Motivation & Metamotivation & $\begin{array}{c}\text { Meta- } \\
\text { metamotivation }\end{array}$ \\
\hline $\begin{array}{c}\text { goal } \\
\text { promotion - } \\
\text { prevention theory }\end{array}$ & to play Alterac Valley & to have fun & to forget problems \\
flow & promotion & prevention \\
\hline
\end{tabular}

The results of the current study could also be interpreted in a biochemical context (Koepp et al., 1998). Dopamine is associated with rewardseeking behaviors (Arias-Carrión \& Poppel, 2007) and its role can be described by differentiation between 'wanting' and 'liking' (Berridge \& Robinson. 1998). The role of 'wanting' is not to mediate hedonistic impact but rather to mediate the incentive salience of rewards, modulating their motivational value. 'Liking' is a hedonistic pleasure of consuming a stimulus, an emotion lacking motivational characteristics. In mice, for example, increased dopamine may enhance 'wanting' sweet rewards without increasing the 'liking' of sweetness (Pecina at al., 2003). The differentiation between 'wanting' and 'liking' may help understand addictive 
behaviors: drug, gambling, and game addictions. A cocaine user may be excited by the drug, which may be a source of vitality and self-confidence for him or her. In the case of gamblers, the vitality and self-confidence that lead to risky decisions may be influenced by the illusion of control or unrealistic optimism biases (Abler at al., 2009). Finally, in players vitality would manifest itself in an almost unlimited satisfaction of needs created while playing a game, feeling the power, becoming stronger and stronger. And this state can be described in terms of the interaction between eudaimonistic flow and excitement.

\section{Conclusions}

The current study shows strong empiric evidence for the heterogeneity of the flow state and the way its eudaimonistic component combined with the experience of excitement influences game (Internet) addiction. The study also sheds light on the way addicted individuals - those who experience lower satisfaction with life - find their way to well-being. However, it is important to note that the results presented here are based on exploratory factor analysis and further research should focus on improving the flow scales. In particular the purposefulness component needs to be carefully developed or reworked. Also, the model is based on correlational analysis; future experimental design might confirm a causal relationship between addiction and its predictors. Finally, the participants of the current study were not game (Internet) addicts in clinical terms. It might be worth exploring how the eudaimonistic flow-excitement model would describe a 'real' addicts population. The model presented here can also be interpreted in terms of existential analysis and logotherapy (Frankl, 2006), with a wide range of possible implications for Internet and game addiction therapy.

\section{References}

Abler, B., Hahlbrock, R., Unrath, A., Grön, G., Kassubek, J. (2009). At-risk for pathological gambling: Imaging neural reward processing under chronic dopamine agonists. Brain, 132(9), 2396-2402. 
Arias-Carrión, O., Poppel, E. (2007). Dopamine, learning, and rewardseeking behavior. Acta Neurobiologiae Experimentalis, 67(4), 481-488.

Berridge, K. C., Robinson, T. E. (1998). What is the role of dopamine in reward: Hedonic impact, reward learning, or incentive salience? Brain Research Reviews, 28(3), 309-369.

Carver, C. S., White, T. L. (1994). Behavioral inhibition, behavioral activation, and affective responses to impending reward and punishment: The BIS/BAS Scales. Journal of Personality and Social Psychology, 67(2), 319-333. Choi, D., Kim, J. (2004). Why people continue to play online games: In search of critical design factors to increase customer loyalty to online contents. CyberPsychology and Behavior, 7(1), 11-24.

Chou, T. J, Ting, C. C. (2003). The role of flow experience in cyber-game addiction. CyberPsychology and Behavior, 6(6), 663-675.

Csikszentmihalyi, M. (1990). Flow: The psychology of optimal experience. New York: HarperCollins.

Davis, R. A. (2001). A cognitive-behavioral model of pathological Internet use. Computers in Human Behavior, 17(2), 187-195.

Diener, E., Emmons, R. A., Larsen, R. J., Griffin, S. (1985). The Satisfaction with Life Scale. Journal of Personality Assessment, 49(1), 71-75.

Franken, I. H. A. (2002). Behavioral approach system (BAS) sensitivity predicts alcohol craving. Personality and Individual Differences, 32(2), 349-355.

Franken, I. H. A, Muris, P. (2006). BIS/BAS personality characteristics and college students' substance use. Personality and Individual Differences, 40(7), 1497-1503.

Frankl, V. (2006). Man's search for meaning. Boston: Beacon Press.

Greenfield, D. N. (1999). Psychological characteristics of compulsive Internet use: A preliminary analysis. CyberPsychology and Behavior, 2(5), 403-412.

Griffiths, M. D. (2000). Internet addiction: Time to be taken seriously? Addiction Research, 8(5), 413-418.

Griffiths, M. D, Dancaster, I. (1995). The effect of type A personality on physiological arousal while playing computer games. Addictive Behaviors, 20(4), 543-548.

Higgins, E. T. (1997). Beyond pleasure and pain. American Psychologist, 52(12), 1280-1300. 
Kahneman, D., Diener, E., Schwarz, N. (eds.) (1999). Well-being: The foundations of hedonic psychology. New York: Russell Sage Found.

Koepp, M. J., Gunn, R. N., Lawrence, A. D, Cunningham, V. J., Dagher, A., Jones, T., et al. (1998). Evidence for striatal dopamine release during a video game. Nature, 393(6682), 266-268.

McMahan, E. A., Estes, D. (2011). Hedonic versus eudaimonic conceptions of well-being: Evidence of differential associations with self-reported well-being. Social Indicators Research, 103(1), 93-108.

Pecina, S., Cagniard, B., Berridge, K. C., Aldridge, W., Zhuang, X. (2003). Hyperdopaminergic mutant mice have higher "wanting" but not "liking" for sweet rewards. Journal of Neuroscience, 23 (28), 9395-9402.

Ryan, R. M., Deci, E. L. (2001). On happiness and human potentials: A review of research on hedonic and eudaimonic well-being. Annual Review of Psychology, 52(1), 141-166.

Russell, J. A, Weiss, A., Mendelsohn, G. A. (1989). Affect Grid: A singleitem scale of pleasure and arousal. Journal of Personality and Social Psychology, 57(3), 493-502.

Shapira, N. A., Lessig, M. C., Goldsmith, T. D., Szabo, S. T., Lazoritz, M., Gold, M. S., Stein, D. J. (2003). Problematic Internet use: Proposed classification and diagnostic criteria. Depression and Anxiety, 17(4), 207-216.

Scholer, A. A., Stroessner, S. J., Higgins, E. T. (2008). Responding to negativity: How a risky tactic can serve a vigilant strategy. Journal of Experimental Social Psychology, 44(3), 767-774.

Tatarkiewicz, W. (1976). Analysis of happiness. The Hague: Martinus Nijhoff. Walther, J. B. (1999). Communication addiction disorder: Concern over media, behavior and effects. Online: <http://psychcentral.com/ lib/2006/communication-addiction-disorder-concern-over-mediabehavior-and-effects/>. Accessed: $29^{\text {th }}$ December 2018.

Wan, C. S., Chiou, W. B. (2006). Psychological motives and online games addiction: A test of flow theory and humanistic needs theory for Taiwanese adolescents. CyberPsychology and Behavior, 9(3), 317-324.

Waterman, A. S. (1993). Two conceptions of happiness: Contrasts of personal expressiveness (eudaimonia) and hedonic enjoyment. Journal of Personality and Social Psychology, 64(4), 678-691.

Widyanto, L., McMurran, M. (2004). The psychometric properties of the Internet Addiction Test. CyberPsychology and Behavior, 7(4), 443-450. 
Young, K. S. (1996). Psychology of computer use: XL. Addictive use of the Internet: A case that breaks the stereotype. Psychological Reports, 79(3), 899-902.

Young, K. S. (1998). Internet addiction: The emergence of a new clinical disorder. CyberPsychology and Behavior, 1(3), 237-244.

Katarzyna Skok, Ph.D. - psychologist, philosopher, assistant professor at the Faculty of Psychology and Pedagogy (University of Bialystok)

\section{Dwa oblicza przepływu: wstępne wyniki badania uzależnienia od gier}

Abstrakt: Niniejszy artykut ma na celu zbadanie dwuznacznej natury przepływu oraz sposobu, w jaki ten związany jest ze skłonnością do uzależnienia. Rezultaty wstępnej analizy czynnikowej wskazują, że przepływ doświadczany przez graczy ma przynajmniej dwa komponenty, nazwane w niniejszym badaniu przepływem hedonistycznym (bezpośrednie poszukiwanie przyjemności) i eudajmonistycznym (eskapizm). Wyniki analizy regresji pokazują, że 54,4\% wariancji uzależnienia od internetu wyjaśniane jest przez kompetencje życiowe, eudajmonistyczny przepływ w grze, podekscytowanie jako emocję doświadczaną podczas gry oraz irytacjęjako emocję doświadczaną, gdy nie istnieje możliwość grania.

Stowa kluczowe: uzależnienie od gier, przepływ, eudajmonizm, podekscytowanie, eskapizm 